\title{
PRELIMINARY NOTES ON ISLAMIC POLITICAL SPACE: MADINA IN QUR'ANIC DISCOURSE
}

\author{
Hazem Ziada
}

College of Architecture, Georgia Institute of Technology,

485 Oakdale Rd NE, C-24, Atlanta, GA 30307, USA

e-mail: hazem.ziada@gmail.com

\begin{abstract}
Is there a particularly Islamic political space? This paper initiates this long-term research project of spatializing early Islamic history, drawing on the Qur'àn's own spatial discourse. The project seeks to articulate the roles space plays in early Islam's political project. Within this framework, this paper defends the assertion that early Islam presents socio-political relationships which suggest al-madina -a particular conception of the 'city' - as a pivotal locus in this formative political space. Arguments focus on the origins of such a conception in its Meccan Qur'ānic occurrences. Four preliminary features emerge: the madina's association with Qur'ānic journeynarratives and debates of legitimate authority; its environmental connection to a productive hinter-land; its association with a trans-tribal social structure; and its evocation of a public-sphere. Set against the historical background of late-antiquity in which the first Muslim umma appeared and where concurrently the city, as a social artifact, faced threats of dispersion and irrelevance, these features potentially constitute a program for the emergent umma to salvage urbanity itself. In a later paper, evidence from the Prophet's acts in al-Madina (Yathrib) and his Companions' developments of other urban settlements, especially al-Kufa, will be engaged to substantiate the relation between Qur'ānic text and human action.
\end{abstract}

Keywords: Qur'anic verses, political space, Muslim umma, madina

\begin{abstract}
Abstrak
Apakah ada ruang politik Islam? Paper ini adalah awal dari riset jangka panjang untuk meruangkan sejarah awal Islam berdasar konsep keruangan dalam al-Qur'an. Projek ini bertujuan untuk menonjolkan peran ruang dalam politik Islam di masa awal sejarah Islam. Dalam kerangka ini, paper ini berargumen bahwa konsep sosio-politik Islam berakar pada konsep al-madina atau kota sebagai pusat dari terbentuknya ruang politik. Empat elemen dari proses ini adalah: hubungan antara madina atau kota dengan hijrah dan debat tentang kekuasaan, hubungan antara madina dengan daerah pertanian di sekitarnya, asosiasi antara madina dengan struktur sosial suku-suku di daerah tersebut, dan munculnya konsep area-publik. Umat muslim terbentuk di akhir masa lateantiquity ketika penyebaran ruang perkotaan berakibat menurunnya relevansi kota sebagai artefak sosial. Dengan latar belakang ini, keempat elemen tersebut menunjukkan bahwa terbentuknya umat menyelamatkan budaya kota. Paper selanjutnya akan menunjukkan hubungan antara ayat-ayat al-Qur'an dan langkah-langkah yang kita ambil dengan merujuk pada langkah-langkah untuk mengembangkan kota yang diambil Nabi Muhammad saw dan para sahabat di Yatsrib dan tempat-tempat lain seperti Kufa.
\end{abstract}

Kata kunci: Ruang politik, madina, kaum Muslim, al-Qur’an

\section{Introduction: Spatializing Islamic Discourse, Framing the Research Project}

Early in the reign of the Abbasid dynasty, inhabitants of the island of Cyprus - under Islamic rule since the year 28[29] AH/650 CE - rebelled. Desiring to break covenant with them (as is ordained by Islamic law in cases when allies or dhimmis breach treaties or committing treason), the governor over frontier cities corresponded with a number of prominent jurists regarding this political crisis. Judgments professed by the different jurists varied widely and even conflicted. Of relevance here is the advice put forth by three jurists. Yahya ibn Hamza, Abulshaq and Makhlad cited a curious precedent from the time of the Khalifa Omar ibn al-Khattab. Under covenant, the people of 'Arbassus -a frontier-city in the Levant- disclosed Muslim secrets to the Byzantines, thereby breaching their signed trust with the Muslims. Omar offered to double them in payment all property value they own in the city, in return for leaving it. When they refused, he gave them a respite of one year after which they were driven out by force. ${ }^{1}$

The above report cannot be considered typical of early Islamic political history on the frontiers. This history exhibits a wide range of competitive and conflicting currents, which makes any unified diagnosis an aberrant reductionism. Still, the narrative raises a question crucial to this investigation. In the absence of explicit pronouncements from the Qur'ān or Prophetic traditions, and in order to formulate such a judgment: what political culture and ethical resource did Omar issue from - what understanding of text and sanctions did he draw on? The deeper 
question implied here concerns investigating the relationship, within the framework of that referential period, between the authoritative text and interpretive action - a core political problem in Islamic discourse. More specifically, most striking are Omar's alternatives to the people of 'Arbassus. To offer betrayers of trust (from his point of view, at least) twice as much as they own in exchange for the land and city of their dwelling goes a long way towards underlining a basic concern of the early Islamic military and political expansion: namely, space itself. Rather than insist on maintaining authority over the city-peoples or maintain a 'right to rule' over others, Omar's concern centered on territory. This is no idealistic attempt to exclude the notions of conquered peoples as labor or source of tax revenue (as perhaps more apt to a pre-Capitalist society) from the framework of early Islamic expansions, but instead to question whether those constituted central objectives. Given the choice, Omar would rather acquire the land or space, however dear the cost - even if it meant forgoing both tax and labor. Note that the aggressively conscientious Omar allowed his ruling to be transmitted to posterity without conditioning it to particular situations; i.e. it was generalizable as a principle.

This paper initiates a research project which revolves around two main questions: does Islam's early referential period ${ }^{2}$ propose amodel political space? And what, specifically, is the role of space in it? Political space denotes the social practices and underlying conceptions by which a community resolves issues of authority and negotiates difference. The project looks back to this model's moment of inception. As in any historical investigation, retrospection seeks to establish agency and disentangle ideology. It does so through spatializing this formative narrative; through illuminating its spatial categories and spatial components, particularly the Islamic madina in its early phases. As demonstrated below, only such spatialisation can retrieve the dimension of reality in such political practices from their idealized and ideologized versions. This is particularly relevant to the Islamic case, where ahistoricity and aspatiality of early accounts go hand in hand.

In an investigation that departs from conventional Islamic studies by advocating space as subject and evidence, one methodological problem plagues interpretations of the profoundly political relationship between sacred text (knowledge) and practice (action). How readers of the Qur'ān, whether believers or not, and whether in early Islam or present-day modernity, interpret, and internalize the Book will always remain difficult to unpack. ${ }^{3}$ Hadiths, acts, and utterances by the Prophet elucidating interpretations of Qur'ānic text, while authorities of how certain verses should be taken - are only so when confirmed to be his own, and comprehended indepth within their context of utterance. Things are even more uncertain when the actions and utterances of the Prophet's companions are in question; no equivalent care was taken early on to document their traditions. Therefore, as far as this paper is concerned in the early stages of this research project: ascertaining intentionality and causal agency for the Prophet and his companions, in the spatial questions raised here, is untenable. Instead, what following arguments suggest is a measure of consonance between verses and action, which establish possible - even probable - concordance. This measure is necessary to the proposition of Islamic political space as a more-or-less coherent body of thought and practice - at least enough to consider it adequately credible and methodologically admissible to justify pursuit in future investigations.

Within the framework of this longer-term research project exploring early Islamic political space, the present papersketchesits categories and components, their primary objectives and the historical context they engage. The main assertion this paper defends is that early Islam indeed presents socio-political configurations and relationships which suggest madina -a particular conception of the 'city' - as a pivotal locus in this formative political space. Thepaper advances these arguments by tracing the origins of such a conception in its Qur'ānic narratives, in the course of which comparative interpretations of Qur'ānic political space are debated. In a later paper, evidence from the Prophet's acts in alMadina (Yathrib) and his Companions' develop-ments of other urban settlements, especially al-Kufa, will be engaged to test the relation between Qur'ānic text and human action.

\section{Islamic Political Space in Contemporary Literature}

Surprisingly, modern literature on early Islam takes this concern with space as an issue that eschews further interrogation beyond contesting motives and underlying values. Moreover, Modern scholars of disparate persuasions persistently frame the issue of territorial expansion as the period's central, perhaps even exclusive, question of both space and politics.

Daniel Pipes describes the Islamic political ideal as an act of continuous territorial expansion 'in the name of God', where the Islamic umma defined its identity only in opposition to others. Territory was conceptualized in such terms as dar al-Islam, the land over which Islam ruled, and dar al-harb, land yet to be conquered by 'holy war'. Political participation for Muslims thus consisted of partaking in this military vocation, contributing wealth, blood and life. From Pipes' viewpoint this was an unattainable 
ideal; although it theoretically casts Muslims as the political subjects par excellence, in reality it leads to their withdrawal from participation in political life when the ideal proves crushing. Accordingly, Muslims' political 'participation' gradually waned into complete withdrawal by the early Abbasid period (around $205 \mathrm{AH} / 820 \mathrm{CE}$ ); from thereon, rulers resorted to recruiting (and kidnapping) military slaves, mainly from Central Asian and Turkic tribes, to substitute for the lack of citizens 'participation'. Building on Pipes' framework, David Marshall locates the historical origin of this political project of territorial expansion by conducting a study of Qur'ānic punishment narratives: stories of pre-Islamic communities and settlements violently punished by God to avenge their disbelief of His messengers and their 'corruption in the land'. Marshall asserts that the early Muslims' political mandate was formulated at the juncture of the Prophet's (and other Muslims') migration (hijra) from Mecca to Yathrib. Prior to hijra, Marshall argues, the triangular relationship between God, His messenger (plus the believers), and the unbelievers, coexisting within the space of the same town (Mecca), was one where God reserved for Himself the exclusive right to avenge their unbelief and oppression. However, the spatial separation introduced by the act of hijra to al-Madina, transformed the believers themselves into the instrument of God's revenge on unbelievers. For Marshall, this notion of revenge is what colors Muslim military expansion and hence the whole Islamic political project. ${ }^{4}$

Ironically, scholars from the other end of the 'belief' spectrum seem to converge on this point. Sayyed Qutb professed a similar doctrine of territorial expansion as central to Islamic political praxis; however, he grounds it in the notion of Allah's hakkemiyya (rule) over territory. Not unlike Pipes, Qutb characterizes the political role of Muslims as continuous territorial expansion under Islamic authority. However, Qutb's position departs from that of Pipes when his thesis weights with emphasis the purpose of this expansion: the spread of divinely inspired just-rule, or divine law. In other words, territorial expansion was not an absolute aim for purposes of glory or revenge, but conceived as an obligation for Muslims in-front of God: as a duty of emancipation towards other nations.

It is thus that modern scholarship, on both sides of the 'trenches', views Islamic political space at its historical origin: as a project of military expansion in search of identity, booty or labor. Both schools of thought rely primarily upon interpretations of Madinan Qur'ānic verses, themselves heavily contingent on the atmosphere of conflict that al-Madina years witnessed. Such characterization of the Islamic political project is unsustainable. Placed within the wider context of Qur'ānic narratives, in both Meccan and Madinan verses, it is immediately evident that expansion and punishment were not the sole models according to which the relationship between God, messengers and unbelievers unfolded. Abraham's peaceful migration and founding of cities in Mesopotamia and Arabia exemplified starting a new faith in a settlement founded afresh. David and Solomon feature throughout the Meccan verses as founders of unparalleled kingdoms and builders of grand edifices and cities (al-Naml, 27). If the punishment narratives comment on the relationship between God, messenger and unbelievers in Mecca, the foundation and building narratives are no less pertinent. In the Qur'ānic story of Solomon, the Queen of Saba' (Sheba) submits to Solomon's God at the sheer power of his architecture - his overwhelming display of technique and skill in building a palace of 'glass' (al-Naml-27:44). Another Qur'ānic example comes in the Meccan chapter on Joseph, whose rise in Egyptian urban society depicts a political success model that is non-vengeful and of long term environmental significance. Once peacefully victorious in Mecca, Prophet Mohammed (pbuh) directly quotes Joseph's declaration of forgiveness towards his brothers (12:92). Moses' and Aaron's stories provide even more pertinent examples, especially in Taha (20), chronologically from the third Meccan period, when the believing community was at its lowest ebb physically and economically besieged in the abuTalib clan valley. At the height of persecution, the nascent community of Muslims was consoled not by images of revenge and punishment, but rather reminded of the dynamics of building a new society.

This quick excursus illustrates two points. First: the Meccan verses potentially played a far bigger role than currently acknowledged in the formulation of the Islamic political space. If so, then the roots of this political space can be argued to stem, not from a contingent context of conflict, but rather embedded in a broader perspective of forging society - and space. The faithful community was being practically and conceptually educated in the arts of forging an umma. Second, challenging the modern monolithic explanation of Islamic political space as one of continuous territorial expansion, it begs the question once again: what then did space mean in this nascent project? How does the Qur'ān itself formulate for the faithful this political space?

\section{Islamic Political Space: An Alternative Formulation}

This section argues that Meccan verses tender an alternative framework for understanding and action in the landscape, and a particular conception of the madina, particularly crucial for this historical phase of late antiquity. A brief chronology of Meccan verses is warranted here. According to the chrono- 
logical classification adopted by abul-'Ela alMawdūdy, the thirteen Meccan years are divided into four periods. ${ }^{5}$ It should be noted first, that "comparatively very little material is available in regard to the background of the revelation of Meccan Suras, whereas the period of revelation of all the Madani Suras is known or can be determined with little effort", as al-Mawdūdy states. Meccan history was not compiled with as much detail and precision as that of al-Madina, which points to a larger problem in Islamic scholarship. More emphasis is commonly laid on the conflict years, partially as a result of the plethora of data, traditions and materials - while the Mecca period receives less attention. It also makes the periodization of the Meccan years rather conjectural; aside from a few authentic Prophetic traditions concerning some suras, this periodization is more dependent on the "internal evidence" of the different suras: "the topics they discuss, their subject matter, their style and direct or indirect references to the events and occasions of their revelation". Meccan periodization works as follows. The first period is about three years long, and stretches between Mohammed's (pbuh) "appointment as a Messenger and his proclamation of Prophethood; the call for faith was secretive throughout. Two years long, the second period traces the development of opposition to the declared message starting with opposition by individuals and growing into banded persecution, coupled with increase in harshness and abuse. During the third period, which lasted for some six years (until the death of the Prophet's uncle and wife), such persecution became so brutal that some Muslims immigrated to the justice of the Abyssinian king; social and economic boycott were practiced against the Muslims during that period. The last three years in Mecca constitute the fourth period, when the Prophet (pbuh) attempted to call surrounding tribes and settlements to the faith, culminating in his success in winning over al-Aws and al-Khazraj, whereupon he migrated to their town, Yathrib, in 622CE.

Also worth stressing is that Qur'ānic verses play numerous roles in relation to their contextual events of revelation, and with regard to later events and more general conditions. It is unwise to constrain, along with Marshall and others, such a role to commentary on prior and concurrent events; Islamic scholars have long shown that the Qur'ān also anticipates events, not just by foretelling them, but also by preparing the emerging community for their potential occurrence.

Verses discussing the human artifact of madina are considered in this light. Throughout the Qur'ān, the term madina (singular) occurs thirteen times in ten chapters; nine such occurrences in Meccan chapters, the remaining four in Madinan ones. Its plural form Madā'in occurs three times in two suras - both Meccan. ${ }^{6}$ In the chronological periodization of revelation, both forms are completely absent from the first two Meccan periods: the first five years of the Prophet's call in Mecca (c. 609-614 CE). In the third and fourth Meccan periods, they persist from the fifth year to the very last year in Mecca before hijra. Once in Yathrib, both singular and plural forms disappear during the first five years; the singular form re-emerges halfway through (c. 5 AH/627 CE) and until the end of the ninth year. In the Meccan occurrences, the term denotes, not a specific settlement, but a generic type; significantly, in Madinan verses the term is exclusive to Yathrib, which at some point during that period became al-Madina (the-Madina).

1. Two Meccan Suras are key to grasp some basic features of this political landscape, delicately historicized al-Kahf-18 and Yūsuf-12. Al-Kahf is a spatial saga that starts within a confined cave (and an associated mention of a madina), but gradually unfolds in scale from garden to village to end in two consecutive journeys across expansive landscapes. This suggestive string of spaces incites focused future probing indepth; suffice it here to consider its bookends. The chapter commences with the story of the group of believers who, facing religious persecution in their city, took refuge in the confines of a secluded cave. Securely isolated, they remained undiscovered for some three hundred years, during which they were miraculously put to sleep. When finally awake and unaware of the duration they spent slumbering, they send one of them into "al-madina" for food and supplies, only to be discovered and the miracle exposed to the city, which, by then, had become a population of believers. For the early umma-intraining, contrasting the spaces of cave and city scaffolds a political quandary and underscores a historical challenge. It posits the knowledgeable cave-sleepers against those who took action in face of persecution until the faith's political authority was established over both city and surrounding landscape, “... those who prevailed over their affair..." (al-Kahf-18:21) ${ }^{7}$. Significantly, the Qur'ān makes such distinctions using the socio-spatial constituents of late-anti-quity. As the Roman Empire economically waned, the city gradually lost its role as the dense center of administration, taxation and culture in its territorium. Diffuse population densities prevailed in smaller villages and hamlets across Mesopotamia, the Levant and in Western Europe. Symptomatic of this dispersed landscape of late antiquity in which the Muslim community first emerged, the cave-city dualism signals the threats facing urbanization then, and on which I will expound later. 
The chapter's third narrative again problematizes, to what seems like an impasse, the issues of knowledge and action, as Moses crosses a landscape following one of God's “... servants, on whom We had bestowed Mercy from Ourselves and whom We had taught knowledge from Our own Presence" (al-Kahf-18:65). Moses' limited human knowledge remains at odds with the "servant's" divinely-inspired action; the latter finally parts with Moses as knowledge and action seem irreconcilable in a model applicable to a human project. But it is the final narrative of dhul-Qarnein which seems to suggest a model where knowledge and human action are commensurate. Dhul-Qarnein travels the extents of what seems to be an expansive landscape, but as one for whom "We established his power on earth, and We gave him the ways and the means to all ends" (al-Kahf-18: 84). On his way, dhul-Qarnein comes across several peoples, where he is delegated by God "either to punish them, or to treat them with kindness" (al-Kahf-18: 86-8), according to their righteousness. The powerful dhul-Qarnein demonstrates for later Muslims the act of spreading justice across a landscape. Till then the reader is unaware of why dhul-Qarnein deserved this power and status. The problematized entangle of knowledge and action is resolved in dhul-Qarnein's final stop on his journey. In this elaborated part of the narrative (verses al-Kahf-18:92-8), the dialogue between dhulQarnein, the powerful believer, and the people torn by war and oppression, perhaps models dialogues Muslims should later conduct with other peoples as they extend the territory of divine law and faith. Far from chasing honor and wealth, dhul-Qarnein turns down tribute; more significantly, he contributes the knowledge of building the dam. It is curious how all elements employed in the dam belong to the existing context; raw material: iron and lead; energy: fire; labor: the peoples themselves. Dhul-Qarnein and his company contributed the technical knowledge. ${ }^{8}$ Significantly, the act of building (spatialmanipulation) resolves a political conflict, terminating a state of war and consolidating a settlement; space, not punishment, is the primary tool of this politics.

In the Meccan Qur'ānic chronology, this sura belongs to the third period's early days. Five years into the Prophet's call to faith, the emerging community faced severe opposition and harsh persecution. At this critical juncture, initial calls for migration emerged; indeed, the first hijra to Abyssinya soon took place (c.614-5 CE). With hijra arise questions of the universality of the faith and its dissemination in unlimited landscapes; significantly, with the earliest Qur'ānic accounts of journey-narratives in such landscapes come the initial occurrences of the term madina in revelation chronology. Their co-introduction prefigures the related dynamics of hijra and madina throughout later verses (and in Muslims' political practice). Underlining all narratives of historical peoples and settlements being called to faith (eventually punished or not) is the unavoidable interrelationship between faith and the political mode of 'prevailing over' people and landscapes. Directly (in most cases) and indirectly (in a few others), Qur'ānic journeynarratives unfold as an escape from injustices of disbelief or as a pursuit of justice elsewhere - or both. What such narratives question are issues of the legitimacy of authority, and by what values this authority is extended over society and space. In al-Kahf's first narrative, the madina is abandoned for the cave; in the final narrative, the settlement is consolidated. They anticipate other journeys and models throughout the Book in search for freedom of faith and just political practice: Noah's Ark, the flights of Lūt, Hūd and Saleh from their persecutors; the Israelites' recurrently-narrated exodus from Pharaoh's oppression and their subsequent attempts to consolidate a just, pious society which, as a narrative more developed than others, adds more 'twists' to the journey-narrative plots: what started as a flight from the city in Egypt paused temporarily in the wilderness maze.

2. While ecological concerns are mentioned in other chaptersit is in the second key sura, Yüsuf-12 (from the final Meccan year), that the environmental dimension is stressed and prob-lematized as a political question. But it would be useful to situate this in its historical framework. Economic historian Andrew Watson has noted that the "rapid spread of Islam into three continents in the seventh and eighth centuries was followed by the diffusion of an equally remarkable but less well documented agricultural revolution". This 'revolution' originated with the transfer of many new crops from India across to Islamic territories. The list of crops is impressively long, and so was the magnitude of achievement. ${ }^{9}$ Three strategies were involved: First, introducing new farming techniques: including year-round agriculture in two or three rotations (thus introducing new seasons) as well as extensive reclamation of what has hitherto been considered wasteland. Second, a substantial extension (even complete reconstruction sometimes) of irrigation systems throughout the conquered lands; those inherited from ancient engineering had largely fallen into disrepair by the seventh century, and were illsuited to serve increased water demands from rotation systems and new seasons. Third, the 
formulation and expansion of knowledge related to agriculture, such as revolutionary classifications of soils, farming techniques, and fertilizer applications. ${ }^{10}$ According to Watson, the impact of this environmental and economic phenomenon cannot be overestimated. Both challenge and achievement are even more bewildering if we consider that they were undertaken by "a people not commonly thought to have green thumbs". Little in North-Arabians' recent pre-Islamic history pre-figures this sudden, overwhelming affinity for agriculture.

Even if Watson's problematic terminology of 'revolution' is dismissed, an environmental 'concern' together with an achievement of considerable magnitude are still borne by historical evidence. What induced the Arabs to instigate such large-scale agricultural and environmental innovations? Watson cites a number of socioeconomic and technological factors as possible instigators. ${ }^{11}$ What this paper suggests is that non-material provocations of this pseudo-revolution stem from Qur'ānic urgings to its readers: the believers' environment role ofişlah fi al-ard. Aside from explicit Qur'ānic verses and Prophetic traditions professing this role, the Book also implies it through subtler discussions of precedents. In an intermediate Meccan chapter, alNaml-27: under David then Solomon, long after the wilderness and Moses death of, the Israelites finally achieved their goal. The outcome was a just and balanced society, as it was rich in culture and built-artifacts; but also developed in environmental sensitivity as exemplified by Solomon himself and his complex relations to the animal world. But again, it is in Yūsuf-12 from the final Meccan years that the madina- environment political relationship is emphatically articulated. Joseph's interpretation of the Egyptian king's almost-surreal dream of “...seven fat kine, whom seven lean ones devour, and seven green ears of corn, and seven (others) withered..." (Yūsuf-12:43) turns out to be a piece of advanced knowledge of agriculture, grain storage and management. ${ }^{12}$ As a consequence of his sound interpretation, Joseph is awarded the office of overseer of "the store-houses of the land" (Yūsuf12:55). The next verse comments: "Thus did We give established power to Joseph in the land" (Yūsuf-12:56). But in more than one sense, Joseph was the product of the city. Although born in the badia (desert), he came to Egypt a young boy as part of a slave trade. Verses relate his growing up in the city: "When Joseph attained His full manhood, We gave him power and knowledge..." (Yūsuf-12:22). The story of his seduction by "Ladies ... in the Madina" (Yūsuf12:30) finally lands him being in prison - a parti- cularly urban institution. Thus by the time Joseph professed such advanced knowledge of agriculture (and dreams) and assumed the office of overseer, he had been greatly transformed by his urban setting. The environment becomes the urbanized-Joseph's field for action: "Thus did We give established power to Joseph in the land, to take possession therein as, when, or where he pleased" (Yūsuf-12:56). As with Solomon, the model of an urban environmentally-sensitive Prophet who administers the land as part of his prophetic tasks forcefully suggests to the Qur'ān's reading-faithful their own mode of environmental action; the madina itself assumes the role of overseeing the surrounding landscape. This is borne by the Mohammed's (pbuh) own later activities in al-Madina and his treatises with other peninsular tribes; this environmental role constitutes no insignificant part of the Islamic political space.

Those two eminently spatial Meccan Suras (alKahf and Yūsuf), chronologically considered, arguably formulate some basic features of this Islamic political space: models for commensurate knowledge and action which legitimate authority over landscapes; deep sensitivity for the environment; and concern over the plight of the city in late antiquity. Significantly, both suras articulate all this absent notions of war and revenge. Nowhere in the narratives of dhul-Qarnein (al-Kahf18:83-98) or Joseph's ascendancy to political power, do we encounter battle as a theme. In both cases, authority is extended over the landscape through the agency of knowledge - divinely inspired perhaps, but applicable human knowledge. Unlike the miraculous slumber of the cavesleepers; unlike the divine intervention to conclude the argument between the disputants in the gardens; unlike Moses' companion, whose epistemological communion occurs directly with God; and even unlike the story of Solomon, whose unparalleled kingdom was built by the exceptional skills of subjugated jinnies - unlike all this, dhul-Qarnein's and Joseph's commensurable human knowledge and action converge to constitute their claim to authority.

3. If Yüsuf-12 demonstrates clear contrasts between bedouin and urban contexts emphasizing the latter's role in a productive hinterland, sura alHijr-15, from the final Meccan period, seemingly conflates qarya with madina. Throughout the Qur'ān, the narrative of Lūt's people occurs in a qarya. ${ }^{13}$ However, in the single occurrence of alHijr, it is exceptionally referred to as madina (alHijr-15:67). This problematizes a whole set of settlement-categories employed in the Book including: qarya, madina, balad and misr; what differentiates between them? While an indepth 
study of such terms merits another investigation, suffice it here to argue that the Qur'ānic qarya is a generic term denoting any form of human settlement. This is borne by a long list of occurrences, ${ }^{14}$ but particularly the following verses: al-Isra'-17:16, -17:58 and al-Naml-27:34, where a general pronouncement regarding human experiences with divine call to faith is made. The term qarya then emerges as one which covers all other Qur'ānic terms describing human settlements under its rubric: madina, balad and misr. ${ }^{15}$ This may be corroborated by its root verb qarr, which means "to settle down". That this was and perhaps remains - the way Arabs and peoples of Bedouin origin call settlement is suggested by another verse in Yūsuf-12:82, where Jacob's sons describe the Egyptian city they were in (where Joseph resided) as qarya.

But why would the description of Lūt's settlement as madina occur only once as compared to its numerous other generic descriptions as qarya? Indeed, the question begs itself: when and why does qarya, a generic-settlement, become or is qualified as, madina? The answer arguably lies in the environmental bond to its hinterland addressed above, but also in other features inferable from the Book. Surveying the different narratives of Lūt's people reveals that, unlike other peoples, they are never described in association with a mala' - a social oligarchy particular to tribal societies. ${ }^{16}$ Rather, Lūt's people are consistently called qawm - a more heterogeneous social mix. Additionally, Lūt was an immigrant to their community (al-Anbiya'-21:71), which means that the settlement was more inclusive of foreign elements; that the Qur'ān still called Lūt a "brother" to his people despite his immigrant status possibly implies Lūt's bonding with the qawm during his stay there. Unlike Sho'aib, who was sent as an 'immigrant' prophet, Lūt resided among the people prior to revelation. Hence another dimension of the Qur'ānic madina construct: it gives rise to social affiliations that do not originate in blood-ties, or al-aşabiyya discussed by Ibn Khaldun. Alternative forms of solidarity, based on professional and commercial ties rival, even dominate, așabiyya. ${ }^{17}$ Whether the verse captures Lüt's settlement in a state of transition from a qarya to a madina cannot be confirmed without more historical evidence; however, this exception illuminates a principle: the Qur'ānic madina is associated with a nontribal social structure. In the cases of al-Madina (Yathrib post-hijra) and al-Kufa, overcoming tribalism was a prime objective for the Prophet and his second Khalifa, Omar. ${ }^{18}$

4. Besides non-tribal affiliations, the Qur'ānic madina comes associated with 'public-ness'. In sura
al-Qasas-28, from the third Meccan period, Moses is presented as a figure who moves between exposure and secrecy, public and private. He kills an Egyptian when the city's peoples were inattentive and unwatchful, precipitating his flight from the city to the shadows of Bedouin life (al-Qasas-28:23-4). In sharp contrast to such states of secrecy, isolation and marginalization, the climax of the story sees the Prophet Moses having returned to the city to proclaim his people's cause to Pharaoh - in a most public event, as the standoff between Moses and Pharaoh's sorcerers unfolds in a public space infront of a large audience on the festive yawmul-zeena (Taha-20:59). Joseph's career similarly treks from obliviousness at the bottom of a badia well to the top of urban Egyptian society (Yūsuf-12), where his call to faith is declared. In his Muqaddima, the Muslim historian ibn-Khaldun picks up this distinction when he inscribes the two Arabic urban terms: madina and misr $^{19}$ under the rubric of hadar, explaining the latter as "presence". 20

Within the city itself, its own publicness is contested and divided. Al-Qasas-28 and Yasĩn-36 (from the final Meccan period) observe internal spatial differentiation within the madina itself. For any settlement called to the faith, whether qarya, balad, misr or madina, the Qur'ān relates that inhabitants were divided in their responses to issues raised by their prophet; some accepted his call, some rejected and conflict ensues. Only in the case of a madina, however, do the verses attach this split to a spatial counterpart. In Yasĩn-36, "Then there came running, from the farthest part of the City, a man, saying, "O my people! Obey the messengers"," (Yasinn-36:20; italics added). This echoes Moses' story where, after Moses kills the Egyptian: "And there came a man, running, from the furthest end of the City. He said: "O Moses! the Chiefs are taking counsel together about thee, to slay thee: so get thee away, for I do give thee sincere advice" (alQasas-28:20; italics added). In both cases, the madina is split into center and outlying areas believers are 'sub-urbanites', in some sense. The city's spatial differentiations also come across in Yūsuf-12:18: as the seductress' secret goes public with the city women's gossip, Joseph is jailed away from eyes and ears.

Center and edges, public and private: such subtle connotations of the madina be speak spatial articulation and contestation. In the Qur'ānic madina, one detects the complexities of a spatial system but which consistently revolves around a public sphere. The Qur'ān repeatedly connotes the madina's role with the public sphere of its hinterland, a characteristic lost to cities of the 
seventh century, as well as a site of contestation of publicness within its bounds.

5. This survey of Meccan verses captures prelimnary connotations of the human-social artifact, the madina. At this juncture, it is crucial to resituate such observations in the historical context of late antiquity: wherein Muslims initiated their initial journeys (for dawaa, commerce, as well as wars) into the landscape. The city underwent serious deterioration from late antiquity and into early medieval times (between late-fifth and late-eighth centuries), in conjunction with, if not as a result of, its deteriorated relationship to agricultural and pastoral hinterlands. With that, the city ceased to be the intermediary between the central state and farmers, the primary labor in the period's productive system. The city was caught between the rivalries of church and state. Urban by nature, the church institution gained strength and momentum in a trans-state manner; it collected alms and taxes centrally for its seat in Rome -usurping other urban centers. Simultaneously, to rival the church's power, the state (whether Eastern or Western) tended to decentralize its administrative and fiscal activities, thereby bypassing cities. Tax collection and fiscal administration were thus withdrawn from the city as deep inflation took root as early as the second-century CE; the function of the city as an independent or semi-independent corporation diminished; the role of the city as a center for military activity was also gradually usurped by small defensible Kastra-like settlements from the fifth century onwards. Meanwhile, landholders and elite investments withdrew from the city to reside in the countryside. With widespread deurbanization, settlement-densities declined while population and cultural homogeneity intensified; simultaneously, "exposed hinterlands discouraged large-scale concentrations of resources and market exchange activity". Documents of the Eastern Roman Empire from late antiquity reveal an increasing, more complex role for peasant communities and villages. ${ }^{21}$

But why is the decline of the city of late antiquity a cause of alarm? As some scholars suggested, late antiquity saw a redefinition of both the role and morphology of the city, but not necessarily its disappearance. More cities than not underwent physical and fiscal 'shrinkage', others entered into the emerging ecclesiastical administrative scheme and others were abandoned - yet the city remained in existence, in some form or manner. ${ }^{22}$ However, what this paper suggests is that a number of the city's most important functions were threatened through such redefinitions of humanity's urban artifact: its crucial role in managing the environ- ment productively and sensitively, its inclusiveness of a trans-tribal heterogeneous social structure; and its production of a public sphere.

Accordingly, one may pose the hypothesis that the thrust of Qur'ānic verses, especially Meccan ones, was to reconstitute the madina and the political landscape it engenders in response to this critical historical juncture, but also as firststeps in a longer term project. During the Madinan period, the Prophet's (pbh) 'spatial' activities in Yathrib after hijra in $1 \mathrm{AH} / 622 \mathrm{CE}$ can be interpreted as implementations of this Meccan doctrine. In fact, madina, as a term in Madinan Qur'ānic verses, is used exclusively in the singular definitive form: al-Madina, to describe none other than Yathrib itself transformed. This usage emerges only after about five years post-hijra, in sura al-Ahzab-33; i.e. the term withdraws awhile to reappear in restricted focus on one settlement: home of the new community. Aproposed explanation is that Yathrib attained the status of a madina, not immediately after hijra, but gradually - following a sequence of actions, agreements and decisions by the Prophet and the community through which its internal urban and social structures as well as its role in its hinterland were dramatically transformed. In history and even legal books, emphasis is always laid on military activity during the Madinan years as the political events worth discussing; yet neither less worthy nor less political are the different measures by which the Prophet (pbuh) transformed Yathrib's geopolitical map, from scattered housing-clusters beset by feuds into a coherent, demarcated and protected precinct with an outlying domain of development or hinterland, and - perhaps most significantly - as a locus for 'publicness'.

Yathrib or al-Madina could be seen as the first chapter of a longer-term experiment to realize an Islamic political space. Evidence points to alKufa as the significant next step in this sociopolitical endeavor, and that, perhaps due to the more complex issues it faced, has added further nuance to the political project. Al-Kufa was perhaps Islam's first full-fledged social experiment to create an urban 'utopia' of sorts, emanating from the Qur'ānic concept of madina. The primary architect of this experiment was none other than Khalifa Omar ibn al-Khattab, but one can also argue the pervasion of a mindset among other companions, given their proportionnal exposure to Qur'ānic text and Prophetic behavior. What singles out Yathrib/al-Madina and al-Kufa as probable candidates for the early chapters of this political project is their unique historical condition among peninsular settlements. Tribal societies in northern and central Arabia tended 
to settle each in a himma (called hijr in southern Arabia) or precinct of its own; coalescence between two or more tribes happened in distant juxtaposition and not through mixing - the stronger protecting the weak. Whether, physically, this himma was densely populated or not is beside the point here; it was still not a city in the sense of possessing aheterogeneous social constituency. A settlement frequently cited by scholars as an exception is Mecca - one of anomalous religious status and in a state of major socioeconomic transformation, where tribes forged the Hims alliance agreement a few decades before Islam. Yet even Mecca under the Hims alliance was dominated by one tribe: Qureish, rather than representing a balance of power between equals. A real exception, however, was pre-Islamic Yathrib, where the juxtaposition of two equally strong tribes yielded decades of rivalry and strife. Ironically, this also provided an opportunity to transcend the established norms, and to attempt to forge solidarities in a Muslim umma defined, not according to tribal affiliations, but rather based on the new religion's decrees of equality and justice. Along similar lines, al-Kufa's early population consisted of a heterogeneous composition in which there was a marked absence of large dominating tribes or clans. As such, it afforded the next step in this socio-political cum urban experiment.

\section{Conclusion}

However, elaborating such complex transformations requires the length of another paper with a different methodology focused on reconstructing, and interpreting, al-Madina's and al-Kufa's physical urban spaces from available evidence in historical texts. To summarize, this paper presents a number of connected propositions.

Contemporary scholarship purports that the Islamic political mandate emerged with the conflicts of the Prophet's (pbuh) post-hijra Madinan years, with believers ordained as avenging tools over unbelieving 'others'. In contrast, this paper's first proposition professes that the roots of the Islamic political project should be sought first in Meccan Qur'ānic verses. The fundamentals of this project revolved around rebuilding a just society whose legitimacy was anchored in privileging certain formulations of knowledge and action.

Regarding the domain of such authority, the second proposition states that the early Islamic political project was more concerned with extending authority over the landscape than over peoples and communities; the domain of authority was, curiously enough, space itself. Besides negating revenge as the project's primary motive, it shifts attention to the spatial discourse of Qur'ānic verses - a field heretofore largely unexplored.

Moreover, it is proposed that Qur'ānic verses formulate a spatial-political project, the fulcrum of which is a particular conception of the urban construct of madina. Through tracing the chronological development of the term madina, and its comparison to other Qur'ānic spatial notions such as qarya, the madina reveals itself as a multifaceted entity.

It is an active relation to a productive hinterland; not merely the tax collector and the defense center, but the madina is, moreover, the core for advancing techniques for developing productivity. Within this framework, the massive agricultural transformations of the eighth to eleventh centuries documented by economic historian Andrew Watson are discussed, to suggest a correlation with the Qur'ānic promotion of the madina-hinterland relationship, repeatedly posited by Meccan verses narrating precedents of prophets and historic figures.

The Qur'ānic madina also gives rise to affiliations and solidarities beyond the confines of blood ties and tribal relations, as witnessed in various verses. The claim here is that only within such a context may Islamic ideas of citizenship (brotherhood before Allah) and umma (community) emerge and develop.

Madina is also creative of a political public. It is a moment of density in the landscape which has the potential to generate a discourse among the heterogeneity of peoples and ideas that comprise it - and which simultaneously allows the political authority vested in the madina to be shared among a wider constituency. Late antiquity's urban crisis offers a potential motive for the promotion of this notion of madina 'publicness'. In this paper, the Qur'ānic madina is postulated as a recapture and reformulation of endangered urbanity.

Above propositions and arguments are far from being comprehensive or exhaustive in delineating early Islamic political space, or the fullness of the madina conception within it. Rather than a concluding argument, this paper should be regarded as a first attempt to induce structured discussion among urban historians and theorists the concept and role of the early madina. Questions and anomalies arose have along the way and still beg themselves. A prominent unsettled question is the historical one: in foregrounding the madina's political role, was the Qur'àn addressing the particular crisis condition of late antiquity, rather than proposing a universal formula? Judging by the historically-sensitive verses, this seems to be a more plausible proposition: rather than formulating it in any final form, the Qur'ān initiated the Islamic political project in response to the contextual issues at its historical point of origin. But again, this stipulation remains hypothetical until further investigation. 


\section{Notes and Reference}

1 From: al-Baladhuri, abul-Abbas Ahmad ibn Jabir. Kitab Futuh al-Buldan (translated by Philip KhuriHitti). Columbia University, 1916, pp. 238-243.

2 By early Islam is meant the period stretching between the earliest revelations to the Prophet in Mecca (13 years before Hijra/c.609 CE), up to the end of the age commonly known as alKhilafa al-Rashida, that of the first four Caliphs (40 AH/662 CE). For most Muslims, this temporal span represents a nominal period, against which subsequent judgments and acts should be measured and qualified.

3 Not more so than in the relation between any body of thought and its related action. Thought and practice are not linked through simple causal relations. In fact, politics involves a problematization of this complex relationship.

4 David Marshall. 1999. God, Muhammad and the Unbelievers: A Qur'ānic Study. United Kingdom: Curzon Press; the argument pervades Marshall's book, but especially on pages 123-4, 130, 154, 180.

5 Summarized in AR. Agwan, NK. Singh's (eds.). 2000. Encyclopedia of Holy Quran, Global Vision Publishing Ho. pp.812-4 (based on Syed abu-'Elaal-Mawdūdy's Tafhīm al-Qur'ān, Islamic Publications 1967).

6 See verses al-A'raf-7: 111, al-Sho'araa'-26: 36 and -26: 53. In general, usage of the plural form complements the discussion below.

7 English translations of the Qur'ān used in this paper come from Abdulla Yūsuf Ali's translation, published in Lahore: Sh. Muhammad Ashraf, c. 1970

8 English translations of the verses overlooksubtle differences inthe terminology dhul-Qarnein and the encountered people use. While they call the desired construction a barrier, he terms it after the technical process of actually building it - a berm. This distinction between functional performance and constructional knowledge summarizes the authority that dhul-Qarnein possesses.

9 Andrew M. Watson. "The Arab Agricultural Revolution and its Diffusion, 700 - 100 CE". Journal of Economic History, v.34, issue 1, March 1974, pp. 8-9

10 Watson. 1974. "The Arab Agricultural Revolution”. pp. 9-10.

11 Watson explains this agricultural-environmental 'revolution' as, largely, caused by a conflation of population growth, urbanization and market expansion as well as Islamic land tenure institutions, the competitive spirit that Islam engenders and the agricultural knowledge developed by the need to feed growing populations and markets. Yet this does not explain why this revolution waned four centuries later, by the eleventh century CE, although most such factors were still in place. The claim here is that Watson's indispensable material factors are insufficient to understand this phenomenon -that it was also induced by an inherently environmental concept of ișlah fi al-ard. This 'concept' was heavily dependent on human participation - which explains its gradual waning as this political participation faded centuries later. (Watson, "The Arab Agricultural Revolution", 1974)

12 Yūsuf 12:47-49

13 The following verses describe Lūt's settlement using the generic term qarya: $7: 80 ; 11: 74$; $11: 077 ; 11: 081 ; 11: 89 ; 15: 59 ; 15: 61 ; 15: 68$; $21: 71$; 21:74; 22:43; 26:160; 26:161; 26:167; $27: 54 ; \quad 27: 56 ; 29: 26 ; 29: 28 ; 29: 32 ; 29: 33$; $37: 133$; 38:13; 50:13; 54: 33; 54:34; 54:36; $66: 10$.

14 See the Qur'ānic verses: 6:123; 7:94; 10:98; $16: 112 ; 17: 16 \& 58 ; 21: 95 ; 22: 45$ \& $48 ; 27: 34$; 28:58.

15 Ista'mar is yet another verb used in the Qur'ān to describe the act of settling, although never used as a noun denoting a settlement.

16 As was the case in Mecca of the late sixth and early seventh centuries, the essentially paternalistic mala' was a regime of tribal heads. Indeed, Mecca is never associated with madina in Qur'ānic discourse. The power dynamics of the mala' regime in Meccathroughdar al-Nadwa building are discussed by abdul-Karim in Qureish: From the Tribe to the Central State (Cairo, 1997).

17 In his Muqaddima, ibn-Khaldun depends heavily on the asabiyya concept to explain human society. He sees the Bedouin state - a tribal form of affiliation based on blood-ties - as the basic, historical origin of all other forms of social solidarities. Society, for him, develops from a mode of survival on necessities, into the search for abundance beyond necessity; from a migratory mode to a sedentary one. Hence, human civilization, urban environments and even rural habitats are born of ostentation and divorced from necessity. In contrast, Qur'ānic depiction of the Muslim community (indeed of human society in general) and its discussion of madina, imply a different reading. While blood ties are essential for survival and for some human necessities, they remain inadequate for all other necessary, 'higher' functions of human society and civilization. This is borne by this Qur'ānic pronouncement "O mankind! We created you from a single (pair) of a male and female, and have made you nations and tribes that ye may know one another.... " (al-Hujurat49: 13, italics added). The original Arabic term for 'know' here, ta'arafu, denotes continuity and some measure of intimacy that the English verb stops short of implying. Here also, human societies are two kinds: nations and tribes (sh'ouoob and qaba'il), which contradicts ibnKhaldun's argument that all stem from an initial migratory Bedouin condition. The distinction to be made here is whether some (if not most) such communities coalesced into 
'nations' (shou'b) and settlements, likewise for survival and necessity and forged their sociopolitical and economic institutions within that condition. What ibn-Khaldun insists on is that, given the ostentation and weakness involved in civilization and urbanity, such communities cyclically revert to an original state of 'pure necessity' that is Bedouin in nature. My contention is that both the Qur'ān and our modern knowledge of history belie that claim. (IbnKhaldun, Abdul-Raĥman ibn-Mohammed (748-808 AH/c. 1370-1430 CE). Muqaddimat ibn-Khaldun (ibn-Khaldun's Prolegomena Arabic Original); edited and checked by $\mathrm{Dr}$. Mohammed Al-Iskandarani. Beirut, Lebanon, Dar al-Kitab al-Arabi, 1415 AH/1996 CE.)

18 As a future paper being prepared for publication will argue (based on my Qualifying Paper 'Islamic Political Space' for the doctoral program at Georgia Institute of Technology's College of Architecture, 2001).
19 As a future paper being prepared for publication will argue (based on my Qualifying Paper 'Islamic Political Space' for the doctoral program at Georgia Institute of Technology's College of Architecture, 2001).

20 The Qur'ān contains only one occurrence (2:61) of the term 'misr' where it does not denote the Arabic name of Egypt and six mentions where it does; which makes it methodologically difficult to formulate a Qur'ānic conception of the term. Ibn-Khaldun uses both terms, misr and madina, almost interchangeably and only a vague distinction emerges where he uses misr for a larger madina. (ibn-Khaldun, Muqaddima)

21 The term is used in the Qur'ān in a similar vein (al-Baqara-2:196), although emphasis is not on explaining settlement as it is in ibn-Khaldun's Muqaddima.

22 Pablo Diaz. 2000. "City and Territory in Hispania in Late Antiquity"; in Towns and their Territories. p.9. 